Implementing Leadership Dimensions in an Induction Model: A Conceptual Framework for Beginning Teachers

\section{Lorenzo Cherubini}

\section{Rationale}

Teacher induction models that are not responsive to current 'postmodern discontinuities' (Limerick et al., 1998) and that promote leadership as the property of a 'chosen few' individuals are stagnant in and of themselves. It is apparent that teacher induction cannot be solely concerned with raising beginning teachers' awareness of board and school policy. Neither can it be reduced to aligning a new and experienced teacher in partnership roles. This would seem to be an extension of the supportive yet artificial relationships that pre-service teachers may have shared with their Associates and may not be encouraging masterful pedagogical practices (FeimanNemser, Carver, Schwillie \& Yusko, 1999; Brooks, 1987; \& Huling-Austin, 1990).

Yet it would seem unrealistic to expect faculties of education to single-handedly prepare pre-service candidates for a fragmented and non-redemptive postmodern reality that they have yet to genuinely experience.

Teacher induction, understood as a formal and comprehensive process of initiating beginning professionals into the 'craft' of teaching, could facilitate a natural transition between pre-service education and the inherited responsibilities and pressures of being a classroom teacher.

The majority of mandates in the United States of America for teacher apprenticeship programs "do not rest on robust ideas about teacher learning" (Feiman et al., 1999; 3). While it is important for beginning teachers to be made aware of pertinent organizational protocol the author doubts if this can be the driving force of an induction model since inundation of technical, legal and clerical procedures may be overwhelming.

Typically, it is during the first four to five months of teaching that teachers resign themselves to the 'Survival Stage' and combat feelings of self worth and professional competency (Ryan, 1986). Nemser suggests that their idealistic expectations are often shattered by both newly discovered accountability and the genuine reality of the classroom (1983). Induction models may have been successful in preparing teachers for the wealth of clerical duties and administrative expectations, but seem to be failing in nurturing genuine individual and professional development.

Beginning teachers are evidently becoming disenchanted with their chosen vocation. Morey (1990) reported in The California Experience that approximately 50\% of beginning teachers leave the profession in the first five years while $80 \%$ quit after ten years of teaching (Kronowitz, 1999). An American Department of Education study (1998) cited similar attrition rates for urban districts across the nation $(50 \%$ in the first five years). A 1993-94 United States Department of Education study concluded that $22 \%$ of beginning school teachers abandon their career before the conclusion of the their third year of teaching. A Canadian Teachers' Federation Study (2000) stated that $42 \%$ of Canadian school districts

\section{"believe that teacher retention will be a factor, ranging as high as two-thirds in the Territories and $60 \%$ in Ontario" (p.7).}

Compound this with the influx of new teachers predicted to enter the profession ( $78 \%$ of school districts indicated that teacher retirement would lead to shortages or increased difficulty finding teachers over the next five years) and the need for an innovative teacher induction model is clear (C.T.F., $2000 ; 7)$. It is evident that beginning teachers have not been sufficiently guided and as a result left to cope with the isolation of their self-perceived inadequacies. There is the risk that their potential as teachers is diminished, while their potential as leading professionals is neglected. Ultimately, optimal student achievement may be jeopardized since the correlation between achievement and teacher quality is very significant (Ganser et al., 1999; 69).

\section{A Vision for Teacher Induction}

Teaching is about leading! I share in Andy Hargreaves' (2001) belief that indeed

\section{"there remains great hope and rea- sons for optimism about a future of learning that is tied in its vision to an empowering, imaginative and inclusive vision for teaching and leading as well" (as cited in Crowther \& Kaagan, 2002; 7).}

Crowther et al. (2002) concluded that

\footnotetext{
"consciousness of the power of teaching to shape meaning systems is not a well-developed capacity in many schools, or, indeed,
} 
throughout the teaching profession" (p.34).

I would suggest that the 'consciousness of the power of leading to shape meaning systems' is equally deserving of immediate attention. It would follow, then, that the study of Leadership becomes an integral component of teacher induction models. The presentation of both Leadership concepts and self-management skills to novice teachers would further the formative processes of arriving at their professional identity.

The implementation of a Leadership component into an elaborate teacher induction program does not propose to re-conceptualize the organizational culture of schools nor does it intend to induce beginning teachers into contemplating positions of additional responsibility within school administration.

Instead, it is to equip beginning teachers with the theory, language and emotional competencies necessary to empower themselves in discovering their capacity as leading professionals within the existing educational infrastructure.

Framework for the Conceptualization of the Induction Model

The Leadership component for teacher induction is framed upon Limerick, Cunnington, and Crowther's (1998) Fourth Blueprint design (from herein referred to as $4^{\text {th }}$ $\mathrm{BP})$. In Managing the New Organization, the authors trace the various organizational and managerial mindsets beginning in the early 1900 's, and offer 'blueprint' configurations for each of the four respective paradigms. The $4^{\text {th }} B P$ (emerging in the late 1980's) accounts for the 'discontinuous change' that characterizes the present postmodern era (Limerick et al., 1998; Hassard, 1994).
The text incorporates a sophisticated discussion of managing meaning for and between organizations. The induction model being presented has assumed certain features of the $4^{\text {th }} \mathrm{BP}$. It is important to note, however, that contemporary educational organizational cultures do not seem to be reflective of $4^{\text {th }}$ BP designs. Schools, despite their efforts towards reform, still resemble the industrial era models of a century ago, built upon hierarchy and bureaucratic order (Hargreaves, 1994; Goldberg, 2000; cited in Crowther, Hann \& McMaster, 1999). Hierarchical management is a product of modernism and management education "was developed in an effort to create a force for the rationality of organizations" (Gephart, 1996; 92; cited in Keough \& Tobin, 2001; 2). Educational bureaucracies and their centralized infrastructures are testament to this evolution that Gephart suggests. The significant factor is that educational institutions seem to remain rooted, at best, in modernist principles despite having to function in a postmodern reality that is highly critical of order, hierarchy and traditional management. In fact, postmodern culture "revels in the loss of absolute authority" (Bloland, 1995; 523; cited in Keough and Tobin, 2001; 2).

In response the $4^{\text {th }} \mathrm{BP}$, and hence the principles the induction model is founded upon that will be further discussed in the subsequent pages, promotes the autonomy of individuals within the organization to discover revamped identities. Given the fragmentation of post-corporate reality, Limerick et al. (1998) suggest that managing must transcend hierarchy by celebrating interdependence and by initiating collaborative networking amongst individuals. It is further recommended that the concept of 'lifestream', the fusing of personal and professional identity, be given significant consideration if organizational culture is to be 'socially sustainable' (Limerick et al., 1998).

Darling-Hammond (1997) \& Hargreaves (1994) qualify that if teaching is to emerge as a "leading profession", it is dependent upon "the real life existence of teacher leadership in schools" (as cited in Crowther et al., 2002; 51). An induction to teaching must be reflective of Sachs' (2000; 84-85) values that "constitute the fundamentals of an active and responsible approach to teacher professiona lism"; namely, learning, participation, collaboration, co-operation and activism (as cited in Crowther et al., 2002; 51). The proposed induction model, therefore, aims to develop the professional leadership capacities and identity of beginning teachers through the formation of essentially autonomous collaborative networks. The networks of teacher inductees will be somewhat reflective of self-contained 'action-learning organizations' (as defined by Limerick, Passfield \& Cunnington, 1994) since they will encourage reflection in action, establish learning alliances, develop external networks, create information, empower each individual, and nurture the professional leadership and vision of beginning teachers.

\section{Implementation Design}

\section{I: Diagnostic Assessment}

Limerick et al. (1998) suggest that researchers begin with "a focus on individuals and the ways they construe and construct social action" (p.247). Each inductee will respond to a series of qualitative-based questions that focus upon the Personal, Institutional and Didactic dimensions of beginning teachers (as defined by 
Rosas, 1997). The questions will also aim to identify the extent to which beginning teachers perceive themselves and others as demonstrating what they understand to be 'leadership' characteristics. At the conclusion of the first year of teaching a post-analysis qualitative-based questionnaire can assess the efficacy of the pilot study upon each participant.

\section{II: Exploration}

To perpetuate the existing 'truth' that leadership is a rite of passage granted to a chosen few who manage a bureaucracy of subordinates may be deceiving. These perceptions should be addressed from the beginning of one's career otherwise teachers risk becoming indoctrinated into the misperceptions of organizational cultures that are not socially sustainable. In such an instance, theirs may be a disillusioned truth especially vulnerable to the fragmentation of the postmodern workplace. An induction program in empowerment could prevent such fallacies from becoming readily accepted.

Beginning teachers need to develop the confidence to become leaders within the existing infrastructure. This stage of the teacher induction component, therefore, proposes to objectively educate new teachers to the traditional structures in both management and unionized activity that may in fact impede the genuine empowerment of individual teachers (Limerick et al., 1998).

Taking into consideration Limerick et al.'s (1998) call for collaboration, it is also proposed that the sample inductees (along with the researcher) partake in a 'virtual on-line network' to host pertinent questions, troubling issues and informal reflections throughout the entire induction program. The researcher's role will be to synthe- size on-line discussion between participants by presenting guiding questions at timely intervals. The discussion within the 'virtual network' is not to be appraised by school and board administration. Teachers will be invited to be candid in both their reflections and suggestions to each other. The virtual network, as a component of the induction model, can serve as an accessible and immediate support system for inductees. Membership in the electronic community will foster a 'reflective practicum' and constructionist perspective since "the phenomena of practice in organizations are crucially determined by the kinds of reality individuals create for themselves, the ways they frame and shape their worlds" (Schon, 1987; 322).

\section{III: Experiential Learning and Collegial Sharing}

Beginning teachers will be presented with a series of activities at strategic intervals throughout the induction period (selected reading materials, regularly scheduled meetings, frequent contact with university faculty advisors, and on-line discussions to name a few) that will provide opportunities to clarify their sense of what it means to be a 'leading professional'. Additionally, the presentation of the four principles of the $4^{\text {th }} \mathrm{BP}$ will be couched in excerpts from American Literature to rouse the inductees' emotional and rational capacities while illuminating the central concepts of leadership.

\section{Principle 1:}

\section{'En Route along Highway 66'}

In John Steinbeck's novel, The Grapes of Wrath, the Joad family is victim to the Dust Bowl Depression of the 1930's and forced to migrate from their dilapidated farmsteads in Oklahoma to the promised prosperity of the Amer- ican west. The route is along Highway 66. The journey is painstaking. Only those characters who discover the strength of interdependence prevail:

"The human spirit... all workin' together... one fella kind of harnessed to the whole shebang...we'd keep together on the road an it'd be good for ever'body".

Limerick et al. (1998) call for a system of interdependence whereby each individual is "held responsible by others". The researcher will guide the inductees (through a variety of activities) in considering the images of leadership they have witnessed in their schools by the administrators, department heads and teachers. The cohort of inductees will be presented with not only the responsibility of being interdependent but with leadership opportunities to exert their influence, which may significantly extend beyond the organization. The objective will be for inductees to depend on each other to recognize the discontinuity within the organizational culture, collectively examine coping strategies and most importantly perhaps, celebrate each other's achievements.

\section{Principle 2:}

\section{'The Monkey Rope'}

Ishmael, the central narrative voice in Herman Melville's novel, Moby-Dick, is on deck of The Pequod and tied at the waist by one end of a rope that joins a fellow crewmember who is overboard scrubbing the hull of the ship:

"So that for better or for worse, we too, for the time, were wedded... so, then, an elongated Siamese ligature united us...I seemed distinctively to perceive that my own individuality was now merged in a joint stock company of two...I saw that the situation of mine was the precise situation of every mortal that breathes; only, in most 
cases, he, one way or other, has this Siamese connexion with a plurality of other mortals".

The $4^{\text {th }}$ BP entails a spirit of $c 0-$ hesive teamwork (Limerick et al., 1998). Each beginning teacher will be led to consider the nature and complexity of networking successfully with others. The virtual network will be intended to develop competent and confident practitioners capable of leading thought provoking reflection to support one another's cause. The cohort will also be encouraged to navigate other strategic networks within and beyond the organization for not only support, but for exposure to other inductees across the province, nation and possibly abroad who are thriving in their induction to teaching. The model will present leadership opportunities for inductees to substantiate their sense of self in relation to others.

Principle 3:

'Socially Sustainable Self-Reliance' (in a postmodern context)

Nothing, according to Ralph Waldo Emerson, is "at last sacred but the integrity of our own mind" (1841). The $4^{\text {th }}$ BP advises that collaborative individuals be autonomous. Participants must be given the right to make their own decisions and have opportunities to make unique contributions to the greater cause. Autonomy "in a collaborative relationship presupposes that the relationship draws its strength from its own perceived value, not from coercion" (Limerick et al., 1998; 121). Through selected readings and small group discussion, the researcher will provide beginning teachers with opportunities to determine how the concepts of 'individualism' and 'collaborative individualism' are significant to them as leading professionals
Limerick et al. (1998) describe "social sustainable" organizations as those that "coexist with, and are interdependent with, others. They are boundary-less systems that draw on society for energy and life" (p.195). The induction model aims to support beginning teachers in discovering both a self-sustaining and fulfilling coexistence and interdependence with others. To exercise leadership that is not defined by bureaucracy may in itself prove to be most liberating.

\section{Principle 4: \\ 'Attainable Felicity'}

Ishmael, in Melville's MobyDick, reflects upon the self-transcendence he experiences immersing his arms in the enormous tubs with other crewmembers to squeeze the globules from the whale's precious oils:

"Come, let us squeeze hands all round; nay, let us all squeeze ourselves into each other; let us squeeze ourselves universally into the very milk and sperm of kindness... attainable felicity is not placing it anywhere in the intellect or the fancy; but in the wife, the heart, the bed, the table, the saddle, the fire-side; the country; now that I have perceived all this, I am ready to squeeze case eternally".

$4^{\text {th }}$ BP networks flourish on the synergies of loosely coupled systems (Limerick et al., 1998). In their reflections, beginning teachers will be asked to consider the dynamics that occur when beginning and novice teachers exercise leadership even in its simplest forms. The nature of each activity within the induction process, be it a selected reading that is distributed to the cohort or a monthly meeting with the group to discuss certain initiatives, is to contribute to a 'consciousness-raising' experience for beginning teachers that directs and legitimizes the "emotional energy and the joy of work"
(Charan, 1991). Ultimately, the induction model can be examined for its potential to empower each inductee with the confidence to discern 'attainable felicity' amidst the fragmentation and discontinuity of the postmodern era. This process may be in and of itself most fundamental to what it means to be a leading professional.

\section{IV: Capacity Building}

The $4^{\text {th }}$ BP paradigm recognizes that institutional roles cannot determine one's identity since systems of action are transient and provide "flimsy templates for definitions of identity". Individuals, thus, resort to 'self-definition as an axis of continuity' (Limerick et al., 1998; 109). Given the conflicting organizational realities that exist inside and outside of contemporary schooling, it would be safe to presume that beginning teachers especially deserve opportunities to arrive at a genuine understanding of self in order to maximize their leading professional capacity. The researcher will guide inductees to contemplate the forms of sustainability (if any) that schools appear to be committed to. The issue of selfmanagement will be a critical consideration within the induction model. Only then can the focus be on inducting teachers to a harmonious 'lifestream' so that they may discover an 'engaged' sense of fulfillment.

The objective is to employ the 'reflective practicum' of the networks to address issues of confidence, competence, emotional strength and trusting instincts. "Being overwhelmed by the requirements of a profession that one felt prepared to enter can generate self-doubt, frustration, and anxiety as novice teachers scramble to understand the fundamental requirements of the role of 'teacher'" (Russell \& McPherson, 
2001; 3). (See also, Berliner, 1994; Carre, 1993; Ethell \& McMenimam, 2000; Etheridge, 1989; Goodman, 1987; Hatton, Watson, Squires \& Soliman, 1991; Housego, 1994; Kagan, 1992; Kane, 1991; McPherson, 2000; Olson \& Osborne, 1991; Ryan, 1970; Smith \& Shapson, 1999; Snow, 1988; as cited in Russell et al., 2001). So much of teaching and leadership seems to rest in the emotional and social realms. Since managing one's emotional development can be nurtured, it would seem logical to introduce it at the onset of a teacher's career (Weisinger, 1998). The induction model espouses to foster discussion between new teachers throughout the entire induction period. Critical to this induction program is empowering new teachers to experience heightened self-awareness.

Research suggests that induction models have and currently address the need to support new teachers. Means of psychological support are designed to assist new teachers in coping with stress (Gold, 1996; 561; Kronowitz, 1999). Given the staggering figures of teacher attrition in the first five years, such strategies appear to be merely 'band-aid' solutions. This component of the induction model aims to create a sense of fulfillment in beginning teachers that allows them to 'engage' in an understanding of self while developing their leading professional capacity.

\section{Recommendation and Conclusion}

The process of inducting new teachers in ways that nurture Leadership is fundamental to their growth since teachers should perceive themselves as leading professionals with a "clear sense of what must be accomplished...an ability to motivate and inspire others, and a willingness to accept responsibility for results" (DuFour et al., 1998; 198). It is recommended that this model of teacher induction in empowerment be implemented to determine its proficiency in facilitating the inductee with a means to transcend what is often a non-redemptive reality. Teaching and leadership can no longer be presented in distinct and non-related classifications. It is further recommended that the model empower teachers to be motivated, dynamic, emotionally competent leaders. This vision of a teacher induction model is indicative of the interdependence espoused by Fourth Blueprint principles: conversations, language and realities within the network of confident, trusting and empowered individuals that are mutually constructed and socially sustainable.

\section{References}

Avolio, B. \& Bass, B. (1988). Transformational leadership, charisma, and Beyond. In J. Hunt et al. (Eds.), Emerging Leadership Vistas (pp.29-49). Lexington: Lexington Books.

Benner, P. (2001). From Novice to Expert. New Jersey: Prentice-Hall.

Bloland, H.G. (1995). Postmodernism and higher education. Journal of Higher Education, 66, (5), 521 559.

Brooks, D.M. (1987). Teacher induction: A new beginning. Reston, VA: National Commission on the Teacher Induction Process, Association of Teacher Educators.

Brown, J.S. \& Gray, E.S. (1995). The people are the company. Fast Company, November.

Canadian Teachers' Federation. (2000). Recruiting Qualified Teachers Will Be More Difficult in the Future. Ottawa: C.T.F. Office.

Charan, R. (1991). How networks reshape organizations - For results. Harvard Business Review, Sept Oct, pp. 104-15.

Combs, A., Miser, A., \& Whitaker, K. (1999). On Becoming a School Leader: A Person-Centered Challenge.
Virginia: Association for Supervision and Curriculum Development.

Crowther, F., Hann, L., \& McMaster, J. (1999). Leadership for Successful School Innovation: Lessons from the Innovation and Best Practice Project. Report from the Innovation and Best Practice Report to DETYA. University of Southern Queensland.

Crowther, F., Kaagan, S., Ferguson, M and Hann, L. (2002). Developing Teacher Leaders. Thousand Oaks: Corwin Press.

Csikszentmihalyi, M. (1990). Flow: The Psychology of Optimal Experience. New York: Harper and Row.

Darling-Hammond, L. (1997). The right to learn: A blueprint for creating schools that work. San Francisco: Jossey-Bass.

DiBella, A., Nevis, A. \& Gould, J. (1996). Understanding organizational learning capacity. Journal of Management Studies, Vol. 33, No. 3, May, pp. 361-79.

Drucker, P. (1999). Managing oneself. Harvard Business Review, March - April, 65 - 74.

DuFour, R. \& Eaker, R. (1998). Professional Learning Communities at Work. Bloomington, Indiana: $\mathrm{Na}-$ tional Education Service.

Emerson, R.W. (1841). Self-reliance. In N. Baym et al. (Eds.), The Norton Anthology of American Literature (pp. 889-909). New York: W.W. Norton.

Feiman-Nemser, S., Carver, C., Schwillie, S. \& Yusko, B. (1999). Beyond support: Taking new teachers seriously as learners. In M. Scherer (Ed.), A Better Beginning (pp. 1-12). Virginia: Association for Supervision and Curriculum Development.

Ganser, T., Marchione, J., \& Fleisehmann, A. (1999). Baltimore takes mentoring to the next level. In M. Scherer (Ed.), A Better Beginning (pp. 69-76). Virginia: Association for Supervision and Curriculum Development.

Gephart, R.P. (1996). Postmodernism and the future history of manage- 
ment. Journal of Management History, 2, (3), 90 - 96.

Gold, Y. (1996). Beginning teacher support: Attrition, mentoring and induction. In J. Sikula, T.J. Buttery \& E. Guyton (Eds.), Handbook of research on teacher education (pp. 548-594). New York: Macmillan.

Goldberg, M. (2000). An interview with John Goodlad. Phi Delta Kappan, September, 82 - 85.

Goleman, D. (1997). Emotional Intelligence. New York: Bantam Books.

Goodland, J. (1990). Teachers for our Nation's Schools. San Francisco: Jossey-Bass.

Guyton, E., \& McIntyre, D.J. (1990). Student teaching and school experiences. In W.R. Houston (Ed.), Handbook of Research on Teacher Education (pp. 514 - 534). New York: Macmillan.

Hargreaves, A. (1994). Changing Teachers, Changing Times. London: Cassell.

Hassard, J. (1994). Postmodern organizational analysis: Toward a conceptual framework. Journal of Management Studies, Vol. 31, No. 3, May, pp. 303 - 24.

Huling - Austin, L. (1990). Teacher induction programs and internships. In R.W. Houston (Ed.), Handbook of research on teacher education (pp. 535-548). New York: Macmillan.

Huling, L. (1998). Early fixed experiences in teacher education. ERIC Digests: December. The Induction of new teachers. (1990). In Promising Practices: New Ways To Improve Teacher Quality. September, Chapter 5.

Keough, T. \& Tobin, B. (2001). Postmodern leadership and the policy lexicon: From theory, proxy to practice. Prepared for the 2001 Pan Canadian Education Research Agenda Symposium - Teacher Education. Quebec City.

Kincheloe, J.L., \& McLaren, P.L. (1994). Rethinking critical theory and qualitative research. In N.K. Denzin \& Y. S. Lincoln (Eds.), Handbook of Qualitative Research (pp.138-154). Thousand Oaks, CA: Sage.
Kronowitz, E. (1999). Your First Year Teaching and Beyond. New York: Longman Publishers.

Lambert, L. (1998). Building Leadership Capacity in Schools. Virginia: Association for Supervision and Curriculum Development.

Limerick, D., Cunnington, B., \& Crowther, F. (1998). Managing the New Organization. Warriewood, Australia: Business and Professional Publishing.

Limerick, D., Passfield, R., \& Cunnington, B. (1994).

Transformational change: Towards an action learning organization. The Learning Organization, Vol. 1, No.2.

Morey, A. (1990). Introduction. In A. Morey \& D.S. Murphy (Eds.), Designing programs for new teachers. San Francisco: Far West Laboratory for Educational Research and Development.

McIntyre, D.J., Byrd, D.M., \& Foxx, S.M. (1996). Field and laboratory experiences. In J. Sikula (Ed.), Handbook of Research on Teacher Education (pp. 171 -193). New York: Macmillan.

Melville, H. (1967). Moby-Dick. New York: W.W. Norton and Company, Inc.

Neck, C. \& Barndard, A. (1996). Managing your mind: What are you telling yourself? Educational Leadership, March. In P. Robbins \& J. Scott (Eds.), Emotional Intelligence (pp. 1 -4). Alexandria, VA: Association for Supervision and Curriculum Development.

Neck, C.P. \& Milliman, J. (1994). Thought self - leadership: Finding spiritual fulfillment in organizational life. Journal of Managerial Psychology, 9 (6), 9 - 16.

Nemser, S.F. (1983). Learning to teach. In L. Shulman \& G. Sykes (Eds.), Handbook of teaching and policy (pp. 150-170). New York: Longman.

Nevis, E., DiBella, A. \& Gould, J. (1995). Understanding organizations as learning systems. Sloan Management Review, Winter, pp. 73-85.
Page, R.N. (1997). Teaching about validity. Qualitative Studies in Education, 10(2), 145 - 155.

Pankow, W. (1976). Openness as self-transcendence. In E. Jantsch \& C.H. Waddington (Eds.), Evolution and Consciousness: Human Systems in Transition. Reading, Mass: Addison-Wesley, pp. 16-36.

Report of the Royal Commission on Learning. (1995). For the love of learning. Toronto: Queen's Printer for Ontario.

Rosas, L.O. (1997). Using participatory action research for the Reconceptualization of educational practice. In $\mathrm{S}$. Hollingsworth (Ed.), International action research: A casebook for educational reform (pp. 219 - 224). London: Falmer.

Russell, T. \& McPherson, S. (2001). Indicators of success in teacher education. Prepared for the 2001 Pan-Canadian Education Research Agenda Symposium. Quebec City.

Ryan, K. (1986). The Induction of New Teachers. Bloomington, Indiana: Phi Delta Kappa Educational Foundation.

Sachs, J. (2000). Rethinking the practice of teacher professionalism. In C. Day, A. Fernandez, T. Hauge, \& J. Moller (Eds.), The life and work of teachers: International perspectives in changing times. London: Routledge Falmer.

Schon, D. (1987). Educating the Reflective Practitioner. San Francisco: Jossey-Bass Publishers.

Senge, P. (1990). The Fifth Discipline: The Art and Practice of the Learning Organization. New York: Doubleday.

Senge, P. (2000). Give me a lever long enough... and single handed I can move the world. In M. Fullan (Intro.), The Jossey-Bass Reader on Educational Leadership. San Francisco: Jossey-Bass, 13 - 25.

Steinbeck, J. (1967). The Grapes of Wrath. New York: Penguin Books.

Sylwester, R. (1997). How emotions affect learning. In P. Robbins \& J. Scott (Eds.), Emotional Intelligence 
services or in-services conducted the O.S.S.T.F. on classroom strategies are clearly significant support mechanisms for a new member on a teaching staff. The subtle power of encouraging the new teacher to participate in such activities can be just as motivating as what an educational leader models.

Successful schools that instruct their students in meaningful ways are dependent on a cadre of teachers who are intent on working in a culture of collaboration, innovation, reflection, and mutual support. As the need for new teachers intensifies and school districts compete for those who choose to engage in this community of learners and who wish to contribute toward education's capacity for thoughtful reform, the role of the collegial school leader is ever more central. By maintaining a clear sense of how teachers make whole school improvement truly work and the concomitant need to promote genuine and trusting relationships among educators both new and veterans in the profession - the principal will ensure the instructional well-being of the students in a school and just as significantly, will enhance the level of teachers' motivation, sense of purpose and professional happiness. It is educational con- siderations such as these that should shape the thinking of a principal intent on leading a school through these turbulent and uncertain times.

\section{References}

Capstick, L. (September 2001). "Let's Focus On What Makes Us Better Teachers". Professionally Speaking. Toronto: Ontario College of Teachers.

Clark, R. (January 2001). "Teacher Shortage In Ontario". OSSTF, 28,7 .

Feiler, R., Heritage, M. and Gallimore,. R. (April 2000). "Teachers Leading Teachers". Educational Leadership, 57,7:66-69.

Lieberman, A. and M. Grolnick. (1997). "Networks, Reform and the Progessional Development of Teachers". In Rethinking Educational Change With Heart and Mind, edited by A. Hargreaves. pp.192-215. Alexandria: ASCD.

Payne, D. and Wolfson, T. (October 2000). "Teacher Professional Development - The Principals' Critical Role". NASSP Bulletin, 84, 618: 13-21.

Peske, H. , E. Liu, S. Johnson, D. Kauffman, and S. Kardos (December 2001). "The Next Generation of Teachers: Changing Conceptions of a Career in Teaching". Phi Delta Kappan 83, 4: 304-311

\section{Implementing Leadership}

Continued from page 12

Sylwester, R. (1997). How emotions affect learning. In P. Robbins \& J. Scott (Eds.), Emotional Intelligence (pp. 1 -6). Alexandria, VA: Association for Supervision and Curriculum Development.

Tardif, M. (2001). Pre-service teacher training programs: Outcomes of recent reforms and new trends towards effective professional training. Prepared for the 2001 Pan-Canadian Education Research Agenda Symposium. Quebec City.

Thoreau, H.D. (1846). Walden. In N. Baym et al. (Eds.), The Norton Anthology of American Literature (pp. 889 - 909). New York: W.W. Norton.

United States Department of Education (1998). Achieving excellence in the Teaching profession. In Promising Practices: New Ways to Improve Teacher Quality.

United States Department of Education (1993-94). National Center for Education Statistics. Schools and Staffing Concerns.

Weisinger, H. (1998). Emotional Intelligence at Work: The Untapped Edge for Success. San Francisco: Jossey-Bass Publishers.
Hamilton Training Advisory Board Commission consultative sur la formation à Hamilton

Preparing today's workforce for tomorrow's workplace.

www.hwtb.on.ca info@,hwtb.on.ca

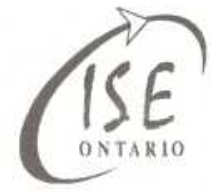

INTERNATIONAL STUDENT EXCHANGE - ONTARIO Programs For Ontario Students secondary \& elementary Reciprocal Exchanges during the school year: 3- and 2-month Reciprocal Exchanges during the summer: 1- month

Summer Credit Courses Abroad in Spain and Costa Rica

Special Program for Faculty of Ed Students

Internship Abroad for 4 to 6 weeks after exams

Summer Seminar in Europe for Ontario Teachers

PLEASE VISIT OUR WEB SITE www.iseontario.on.ca 